https://doi.org/10.37816/2073-9567-2021-60-161-173

УДК 821.161.1.0

ББК 83.3(2Poc=Pyc)

This is an open access article distributed under

the Creative Commons Attribution 4.0

International (CC BY 4.0)

\author{
(C) 2021. A. A. Shuneyko \\ Komsomolsk-on-Amur, Russia
}

(C) 2021. O. V. Chibisova

Komsomolsk-on-Amur, Russia

\title{
DIALOGUE OF TWO INDIVIDUAL STYLES: G. V. IVANOV AND L. N. TOLSTOY
}

\begin{abstract}
G. V. Ivanov's works are evaluated in different ways, but no matter what place analysts give him in the poetic hierarchy, two characteristics remain unchangeable. $\mathrm{He}$ is one of the most significant Russian poets. His poetic language is often focused on reconsidering the experience of his predecessors, which produces a large number of intertextual connections, which represent a constant of poetic language, one of the codes that allow people to see its true depth and pragmatic overtones. The essay introduces a large body of analytical works on G. V. Ivanov focusing on his similarities and differences with various writers, which often reveal controversies with their worldview and interpretations of creativity. For all the variety of works of this type, so far no one has paid attention to the interaction of G. V. Ivanov and L. N. Tolstoy. The second part of the essay proves that the poem "Kak vy kogda-to razborchivy byli..." (How picky once you were...) contains at least six direct textual and structural links with the story by L. N. Tolstoy "After the Ball" and his model of world outlook. These connections capture the complex nature of ambivalent assessment of Tolstoy's position, associated with common stereotyping behavior of the nobility. As the semantic analysis reveals, the lyrical hero of G. V. Ivanov is not only in conceptual relationship with the character of L. N. Tolstoy, but he declares similar stereotypes, characterized by axiological similarity and a single archaic coordinate system.
\end{abstract}

Keywords: G. V. Ivanov, L. N. Tolstoy, intertextuality, world view, interpretation of creativity, stereotypes.

\section{Information about the authors:}

Alexander A. Shuneyko - DSc in Philology, Associate Professor, Professor of Linguistics and Intercultural Communication Department, Komsomolsk-na-Amure State University, Lenina St., 27, 681013 Komsomolsk-on-Amur, Russia. ORCID ID: https://orcid.org/0000-0001-5467-2214.E-mail: a-shuneyko@yandex.ru

Olga V. Chibisova - PhD in Culturology, Associate Professor, Associate Professor of Linguistics and Intercultural Communication Department, Komsomolsk-na-Amure State University, Lenina St., 27, 681013 Komsomolsk-on-Amur, Russia. ORCID ID: https://orcid.org/0000-0002-2709-2465.E-mail: olgachibisova@yandex.ru

Received: October 29, 2019

Date of publication: June 28, 2021 
For citation: Shuneyko A. A., Chibisova O. V. Dialogue of two individual styles: G. V. Ivanov and L. N. Tolstoy. Vestnik slavianskikh kul'tur, 2021, vol. 60, pp. 161-173. (In Russian) https://doi.org/10.37816/2073-9567-2021-60-161-173

$* * *$

\author{
(C) 2021 г. А. А. Шунейко \\ г. Комсомольск-на-Амуре, Россия \\ (C) 2021 г. О. В. Чибисова \\ г. Комсомольск-на-Амуре, Россия
}

\title{
ДИАЛОГ ДВУХ ИДИОСТИЛЕЙ: Г. В. ИВАНОВ И Л. Н. ТОЛСТОЙ
}

Аннотация: Творчество Г. В. Иванова оценивается по-разному, но, какое бы место ни отводили ему аналитики в поэтической иерархии, неизменными остаются две характеристики. Он один из самых значительных российских поэтов. Его поэтический язык часто ориентирован на переосмысление опыта предшественников, что продуцирует большое количество интертекстуальных связей, которые являются константой поэтического языка, одним из кодов, позволяющих видеть его истинную глубину и прагматические обертоны. Поэтому закономерен тот факт, что масса аналитических работ, посвященных Г. В. Иванову, сосредоточивает внимание на его перекличках с различными писателями, часто фиксирующими полемичность в понимании мира и интерпретации творчества. При всем многообразии работ подобного типа до сих пор никто не обратил внимания на взаимодействие Г. В. Иванова и Л. Н. Толстого. Между тем стихотворение «Как вы когда-то разборчивы были...» содержит не менее шести прямых текстовых и структурных связей с рассказом Л. Н. Толстого «После бала» и его моделью миропонимания. Эти связи фиксируют сложный характер амбивалентной оценки позиции Л. Н. Толстого, сопряженной с единством взгляда на стереотипы дворянского поведения. Как показывает семантический анализ, лирический герой Г. В. Иванова не просто находится в концептуальном родстве с персонажем Л. Н. Толстого, а декларирует сходные стереотипы, характеризующиеся аксиологическим подобием и единой архаичной системой координат.

Ключевые слова: Г. В. Иванов, Л. Н. Толстой, интертекстуальность, мировоззрение, интерпретация творчества, стереотипы.

\section{Информация об авторах:}

Александр Альфредович Шунейко - доктор филологических наук, доцент кафедры профессор кафедры лингвистики и межкультурной коммуникации, Комсомольский-на-Амуре государственный университет, ул. Ленина, д. 27, 681013 г. Комсомольск-на-Амуре, Россия. ORCID ID: https://orcid.org/0000-00015467-2214. E-mail: a-shuneyko@yandex.ru

Ольга Владимировна Чибисова — кандидат культурологии, доцент, доцент кафедры лингвистики и межкультурной коммуникации, Комсомольский-на-Амуре государственный университет, ул. Ленина, д. 27, 681013 г. Комсомольск-на-Амуре, Россия. ORCID ID: https://orcid.org/0000-0002-2709-2465. E-mail: olgachibisova@ yandex.ru 
Дата поступления статьи: 29.10.2019

Дата публикации: 28.06.2021

Для цитирования: Шунейко А. А., Чибисова О. А. Диалог двух идеостилей: Г. В. Иванов и Л. Н. Толстой // Вестник славянских культур. 2021. Т. 60. C. 161-173. https://doi.org/10.37816/2073-9567-2021-60-161-173

The poems of G. V. Ivanov contain two divergent prophesies both of the poet's fate and the fate of his poetic texts. According to the first one, they will be forgotten: "Dazhe pamyat' ischeznet o nas..." (Even the memory about us will disappear...). According to the second one, they will return to their homeland: "No ya ne zabyl, chto zaveshchano mne / Voskresnut'. Vernut'sya v Rossiyu stikhami” (But I have not forgotten what was bequeathed to me / to resurrect. To return to Russia in verse). Now we can confidently say that the second prediction has come true.

G. V. Ivanov is one of the most significant Russian poets. His creativity constantly attracts the attention of researchers. He is not ignored by his and our contemporaries, who, when characterizing the dominants of his poetic language, naturally draw attention to the variously understood intertextuality in its many and always artistically justified manifestations. In Russian philological science, there is a group of special studies dedicated to the poetic "roll calls" of G. V. Ivanov with the classics of Russian literature, with contemporaries of the Silver Age and poet's followers.

I. A. Tarasova [17] reveals these "roll calls" in a broad context, focusing her attention on the mental, but not actually linguistic, plane of intertextuality. She considers the metaphorical, ironic, dialogical, enigmatic and paraphrastic intertextual connections of G. V. Ivanov with the works of T. V. Churilina, O. E. Mandelstam, G. V. Adamovich, A. S. Pushkin and I. F. Annensky. N. A. Bogomolov [4] characterizes the features of the approach to citation used by G. V. Ivanov and V. F. Khodasevich, by the example of their quotation fields' intersection. The first author is characterized by an open, non-hiding quote, sometimes becoming unfolded "final". The second one is characterized by a deliberate cryptography, in which behind external connotations are hidden the junctions with completely unexpected texts. In addition, in Ivanov's poems, like Khodasevich's, there are cases when the poem includes not a link to a separate line, but to the whole text of the predecessor. Such a case is the subject of consideration in this article.

A. P. Avramenko considers the common ground of the poetic systems of G. V. Ivanov and A. A. Blok, which he perceives as an ongoing fruitful dialogue of the great classic poets [1]. To it he mainly relates the nature of the authors' coordination with the horror of being. For Blok, it is expressed in the "terrible world" of Russia, for Ivanov, in the terrible world of emigration, but for both, the tragedy of rejection of these segments of reality is connected with the realization of their deep involvement in them. Awareness of tragedy allows researchers to draw bolder parallels. So, L. V. Zharavina reasonably points to significant analogies between G. V. Ivanov and V. T. Shalamov, finding in their works "mental-figurative coincidences" [6, p. 187]. Both are characterized by the identification of camps and foreign lands as spheres of reality unsuitable for human existence. The effect of "double vision" makes Ivanov see a reliable picture of objects which he has never seen. The same effect not only brings closer G. V. Ivanov and F. M. Dostoevsky, but it also carries to both of them the painful knowledge that goes beyond the bounds of the everyday worldview, inaccessible to the ordinary gaze [11]. The researcher establishes the relationship between the lyrical hero of Ivanov's texts and the two characters of Dostoevsky Makar Devushkin and Rodion Raskolnikov, seeing it in the tragic duality of being. 
Binarity in the perception of the world, however, does not distract G. V. Ivanov from transition states. It is in this that M. K. Lopacheva [10] sees his connection with the poetics of I. A. Bunin. Being in the same temporal and cultural context, the authors produce mirror, but essentially identical descriptions of existentially significant situations. This deep interaction does not cancel the diametrically opposite aesthetic guidelines that the writers followed, which, according to O. A. Korostelev and E. V. Kuznetsova [9], led to negative assessments of Ivanov's poetry by Bunin. Similar relations of deep connection and formal opposition are revealed by A. Yu. Zakurenko when he compares the understanding of "emptiness" by G. V. Ivanov and I. A. Brodsky. He argues that Ivanov's borderline is on the ground of being within the limits of life, and Brodsky's borderline is on the other side of being in the world of death [7, p. 574-575]. For Ivanov, emptiness is an extreme degree of spiritual bankruptcy, the bottom of the universe, while for Brodsky it is the highest bar, a place where the soul goes.

A. A. Semina repeatedly pays attention to the interaction of the artistic worlds of G. V. Ivanov and B. B. Ryzhy. She justly comments on the incarnation of the categories of the beautiful and the ugly by the two poets, the juxtaposition of which within the same text enhances the acuteness of perception of the beautiful. In addition, the fusion of these categories allows the authors to achieve a special force of influence on the reader [15]. The same author, referring to the theme of inescapable loneliness and the situation "without a reader", concludes that they are the basis of the unity of G. V. Ivanov's and S. I. Chudakov's poetry [16]. Both poets rarely title their poems, which are characterized by a fragmented lyrical expression. Both the one and the other perceive what is happening in Russia as material for a parody organized by sterilizing various slogans and clichés within the framework of one utterance.

E. B. Shragovits [19, p. 209] lines up the world outlook of F. I. Tyutchev, G. V. Ivanov and B. Sh. Okudzhava. He draws attention to the fact that in this chain Ivanov is the transmission link ensuring the integrity of the poetic tradition, while the object of transmission is the contested nature of the perception of the world.

Meanwhile, N. A. Paporkova establishes the continuity between the artistic worlds M. Yu. Lermontov, I. F. Annensky and G. V. Ivanov, manifested through the translation of the image of the soul and the category of eternity. The most distinctive the specificity of these spiritual and metaphysical complexes is expressed in the concepts of the variously understood "double world". For Lermontov, the "double world" becomes apparent in the conflict of the earthly and heavenly life of the soul, for Annensky - in the hopelessness of the earthly and eternal existence, for Ivanov - in the contrast between human life and the worldly being [14, p. 140]. In "Decay of the atom" by G. V. Ivanov, G. S. Vasilkova finds at least 12 Pushkin reminiscences, the number of which increases due to hidden quotes, referring to the writers' reviews about Pushkin [5]. She claims that in his work G. V. Ivanov also acts as a thinker who believes that the old "Pushkin" literature, based on harmony and humanistic ideals, is becoming impossible in the modern world.

In a pragmatic sense, intertextuality can be perceived in two ways: as an evidence of poetic wealth, and as an indicator of poetic scarcity. In the analyzed works, it is regarded as a special quality of poetry, "organically and convincingly incorporating Ivanov's lyrics into the common single stream of Russian literary classics" [1, p. 126].

It is symptomatic that when establishing various intertextual connections, researchers steadily turn to a single toolkit. It includes concepts: continuity, imagery, double vision and emptiness. Their use allows analysts to draw broad and interesting conclusions. It must be added 
that in addition to the already mentioned authors, the names of such Ivanov's "interlocutors" as A. A. Akhmatova, V. A. Zhukovsky, B. A. Sadovsky [4], N. V. Gogol, G. S. Rozanov [5], N. S. Gumilev, S. A. Yesenin, M. I. Tsvetaeva [1], D. S. Merezhkovsky [11] are mentioned in the works of researchers.

With all the undoubted successes that analysts have achieved in exploring various aspects of G. V. Ivanov's heritage, no one has yet paid attention to the connection of his poetry with L. N. Tolstoy. This connection exists not just a priori, in the sense that any educated person in Russia cannot bypass the aesthetic and ideological discoveries of Leo Tolstoy, but can be traced on the example of a specific text - the tenth poem from "Rayon de rayonne":

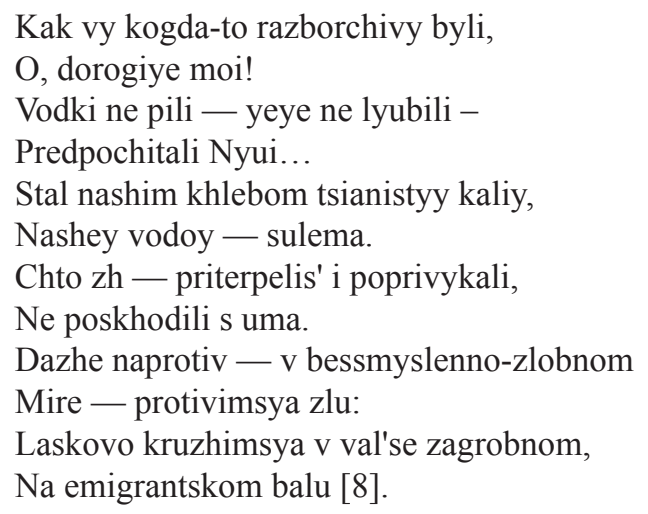

(How picky were you once / Oh my dears! / You didn't drink vodka -didn't love it — / Preferred Nui... / Potassium cyanide became our bread, / Our water is a mercuric chloride. / Well, we got used to them, / Did not go crazy. / Even the opposite - in a senselessly vicious / World - we resist evil: / Endearingly spin in the afterlife waltz, /At the expat ball).

The transparency characteristic of George Ivanov seems to leave no questions about the content of the text. It is about the tragic fate of emigrants. Once discriminating even in drinks, in an alien country, they learned to eat and drink what is uneatable and undrinkable, put up with their fate and lead a meaningless, ghostly existence. The lines of George Adamovich, sent as an epigraph to the poem, are about the same: "Imya tebe neponyatnoye dali. / Ty — zabyt'ye. / Ili — tochneye — tsianistyy kaliy / Imya tvoye" (They gave you an incomprehensible name. / You are oblivion. / Or - more precisely - potassium cyanide / Is your name). The epigraph is the third final stanza from the poem written in 1915, "Kurtku potortuyu s belich'im mekhom..." (A shabby jacket with squirrel fur...). Here the semantics of deadly poison, oblivion, and uncertainty becomes the statement of illusory balancing on the verge of life and death. It should be noted that in Adamovich's poem, which consists of three stanzas like the text of Ivanov, this balancing is connected with emphasized personal experiences, devoid of the epic approach to describing problems inherent to G. V. Ivanov as a whole.

The above surface reading is certainly true. But the depth of the text is not limited to it. Two circumstances give a more complete picture: finding out who the text is about and establishing how exactly this poem is connected with Russian literature at the text level.

Who are "you" = "we" in this poem? It is unlikely that they can be attributed to the number of living people. A person dies after taking potassium cyanide and mercuric chloride. The waltz is called afterlife. It turns out that the dead are described in the poem. The situation presenting a lyrical hero or narrator among the deceased is not exceptional for Russian literature. It is described in various ways. 
In 1863, F. I. Tyutchev wrote the poem "Uzhasnyy son otyagotel nad nami..." (A terrible dream weighed down on us...). It has the lines: " $<\ldots>$ V krovi do pyat, my b'yomsya s mertvetsami, / Voskresshimi dlya novykh pokhoron" (In blood to the heels, we fight with the dead / Resurrected for new funerals).

Close to the depicted by G. V. Ivanov is the situation in Russian poetry recorded A. A. Blok in the first poem from "Dances of Death": a dead man is among the people at the ball. There is only one amendment: G. V. Ivanov describes a ball of the dead. Waltzing, the author himself watches dancing couples from the middle of the crowd. His external look immediately becomes internal. Hence there is the alternation of you - our (we). It reflects a change in the visual angle.

The deep connection of this poem with Russian culture is manifested through several references to L. N. Tolstoy.

The protagonist of the story of Tolstoy's “After the Ball” (1903), characterizing himself in his youth, remarks: "I had a dashing ambler, I skated from the mountains with young ladies (skates were not yet in fashion), drank with friends (at that time we didn't drink anything but champagne; there was no money — we didn't drink anything, but we did not drink vodka, as it is now)" [18, p. 8].

In the first stanza of the poem, Ivanov repeats these lines of Tolstoy in a meaningful and textual way, preserving the tough contrast: "at that time (once)" — "now", the mention of his inner circle: "my dears" _ "drank with friends." The specific nomination of champagne is replaced by its name Nui: " $<$.. > we didn't drink anything but champagne $<\ldots$... = " $<$... Preferred Nui."

Such an exact textual coincidence could be attributed to the fact that G. V. Ivanov, like L. N. Tolstoy, is a nobleman. Although they belong to different generations, they confidently transmit the noble axiomatics, which strictly distinguishes drinks according to the degree of their admissibility in general and in a given situation. The ranking of drinks, as well as the ranking of people, genres, clothing, methods of treatment and much more is a mandatory sign of a state in which the nobility is legitimate. Relatively speaking, any hereditary nobleman knows how to dress for dinner and what drinks he can drink. In this sense, Ivanov and Tolstoy convey an element of the norms of noble behavior. It is noteworthy that, among other things, both had one thought: if a nobleman steadily begins to drink vodka, the state is collapsing.

The perception of vodka in Russian culture and its fixation in the language is a limitless topic. For the issues involved - the semantics of a specific intertextual correspondence two points are relevant. Russian literature steadily translates the stereotype, according to which vodka is a drink of the common people, merchants and commons. As for the noblemen, only that nobleman who is a nobleman only legally but not actually can drink vodka. Such are Stepan Golovlyov, Pavel Golovlyov, Porfiry Golovlyov from the novel "The Golovlyov Family" by M. E. Saltykov-Shchedrin, Baron in the play "The Lower Depths" by M. Gorky, Nazansky from the novel "The Duel" by A. I. Kuprin and others.

After the October revolution, the situation changes dramatically. Well-informed about the peculiarities of the life of Russian bohemia, its representative the artist P. V. Annenkov in his memoirs "Diary of my meetings" repeatedly describes the feasts and revels to which he was a participant. Immediately before and after 1917, vodka becomes the drink of all social strata. Alcohol, moonshine and exotic drinks are added to it: "Alchemists who came with bottles filtered the varnish through seven-day, stale and moldy bread, preparing moonshine: these alchemists were called "Mendeleys" [2]. Tolstoy and Ivanov do not metaphorize or hyperbolize reality. They literally capture one of its features: Tolstoy at the stage of its inception, Ivanov at the stage of its natural end. But they do it not independently of each other. 
There is every reason to state that the poem of Ivanov has not only a reference to the implementation of a generally accepted model of behavior, but a direct reference to the story "After the Ball". Four more matches point to this. Firstly, the lines "Dazhe naprotiv — v bessmyslenno-zlobnom / Mire — protivimsya zlu" (Even the opposite — in a senselessly vicious / World - we resist evil) refer to the philosophical concept of Tolstoy, which is known to the Russian reader in the wording "Neprotivleniye zlu nasiliyem" (Non-resistance to evil by violence). Secondly, Ivanov's poem ends with the word "ball": "Na emigrantskom balu" (At the expat ball) and Tolstoy's story begins with the word ball: "After the ball." Thirdly, Ivanov and Tolstoy's context and representation of the ball differ significantly from the elegiac sublime perception of it, characteristic of Russian literature, as a magical action, anticipating the joy of a new feeling or accompanying it. Indicative in this regard are the poems of V. V. Hoffmann "Summer Ball": "<..> Byl letniy bal mezh temnykh lip" (There was a summer ball between dark linden trees); of K. D. Balmont "Golden Fish": "V zamke byl veselyy bal, / Muzykanty peli" (There was a fun ball in the castle, / The musicians sang). For G. V. Ivanov and L. N. Tolstoy, the ball is not the birth of a new light, but the dying of the old (former) light, it is a border that clearly separates the romantic idyll from reality in its worst manifestations, this is an irreversible boundary, crossing which the heroes are doomed to suffering or meaningless existence. Fourthly, the poem and the story are identical in their three-part composition: (1) the introduction to the story and the epigraph in the poem introduce the problems of the subsequent narration; (2) the narrative of what happened before the ball, and before emigration; (3) the narrative of what is after the ball and after leaving Russia is the collapse of previous ideas about life and life itself.

Four literal matches in three stanzas (48 words) of the text cannot be considered an accident or an insignificant feature of the poetics and semantics of the poem. It is all oriented towards Tolstoy.

The recognition of this leads to another reading of the poem. Before expounding it, it is necessary to note the presence of irony in the text. It is created by a contrasting connection of two mutually exclusive characteristics: "Dazhe naprotiv — v bessmyslenno-zlobnom / Mire - protivimsya zlu" (Even the opposite — in a senselessly vicious / World — we resist evil) and "Laskovo kruzhimsya v val'se zagrobnom" (Endearingly spin in the afterlife waltz). In any coordinate system, a waltz cannot be considered a way of countering evil. Any way to counter evil involves work, while a waltz is an attribute of relaxation. It turns out that the heroes are fighting evil, resting, struggling without any struggle.

It is unambiguously difficult to determine the boundaries of this irony and the scope of its application. It, of course, refers to the lyrical hero and his entourage, since it is they who resist and waltz. Besides this, the ironic rejection may apply to the mentioned concept of Tolstoy, which is quite acceptable. The emigrant milieu was never homogeneous in the perception of Leo Tolstoy and his role in the Russian history. The work of N. A. Berdyaev is indicative in this respect, as it contains the characteristic statement: "And the Russian revolution is a kind of triumph of Tolstoyism" [3]. The area of irony may be the entire situation depicted in the text with its characteristic tragedy and the prospect of hopelessness. In this case, the irony makes the text ambivalent.

If one perceives the semantics of the text outside the ironic evaluation, does not raise the question of the author's assessment of the described segment of imaginary reality, that is, abstracts from personal modality, one can conclude that in general the content of the poem consists of five statements expressed in different ways. 
1 The first stanza contains the assertion that the nobility abandoned the well-established rules of the noble life, discarded them as an unnecessary burden. This information is contained in the presuppositions of the two sentences. The opening sentence "Kak vy kogda-to razborchivy byli, / O, dorogiye moi!" (How picky were you once / Oh my dears!) implies "now you are no longer picky". The next sentence "Vodki ne pili yeye ne lyubili — Predpochitali Nyui..." (You didn't drink vodka - didn't love it — / Preferred Nui...) implies "now you started drinking vodka". The first information is extremely abstract, the second one is extremely concrete, but they are almost identical in semantics. It doesn't even matter if the second is a concretization of the first because both of them can be considered metonymic replacements of a wider meaning "now you abandoned the way of the noble life and all the rules governing it".

2 The second stanza indicates those tragic deformations that occurred after the abandonment. Here the dual semantics is actualized: metaphorical and direct. The metaphorical one suggests that life has become so unbearable that the only way out of it is poison. The direct semantics involves the physical process of poisoning. Both of these readings are a stage in the transition to death of one's own free will.

3 The third stanza claims that the nobility rejected L. N. Tolstoy's preaching of nonresistance to evil by violence and did not follow it. This statement is present in a verbal form: "Dazhe naprotiv — v bessmyslenno-zlobnom / Mire — protivimsya zlu" (Even the opposite — in a senselessly vicious / World — we resist evil). We resist means that in one way or another we oppose, that is, we behave inversely of what Tolstoy called for.

4 The result of these three actions was the tragic exile, loss of the homeland and death. The causal relations between the abandonment of the noble way of life, the rejection of the concept of Tolstoy and exile-death are established by the sequence of statements: first the abandonment, then a description of the deformations that it led to, then the other abandonment and, as a result — the "afterlife waltz".

5 But death is not the final point of suffering of the lyrical hero and his companions. This statement is formulated by a strict compositional reference. The poem accurately repeats the composition of the story "After the Ball", actualizes it in the minds of an attentive reader. All the worst in the story which is a complete collapse of hopes and life itself occurs precisely after the ball. Accordingly, after spinning in the afterlife waltz at the expat ball, outside the text in accordance with the semantic vector, the characters will experience something even worse than death itself. It can be assumed that this is oblivion.

The main constituent component of the poem is a multi-level repetition: at least six references to Leo Tolstoy; compositional identity and a single semantic vector. In addition to them, there is the unity of the character traits of the lyrical hero of the poem and the main character of the story: both tell of personal tragedy. Both do not blame anyone for this tragedy, attributing it to certain fatal laws that are not subject to man. Both after the ball of life find themselves at the ball of death. For both, this transition is associated with some class experiences.

The source of the phrase "laskovo kruzhimsya" (we spin endearingly) may also be the story of L. N. Tolstoy. The national corpus of the Russian language reveals only one use of this phrase among 288727494 — in the text of Ivanov's poem [13]. Therefore, it is individually copyrighted. The impulse of this bold convergence can also be the story "After the ball". This is indicated by the frequency characteristics of units. 
In a story consisting of 3058 words, the words with the root - lask — are used six times: "laskovaya ulybka" (an affectionate smile), "laskovyye, milyye glaza" (tender, lovely eyes), "ta zhe laskovaya, radostnaya ulybka" (the same tender, joyful smile), "laskovo ulybayas"" (affectionately smiling), "laskovoy, pokhozhey na neye, ulybkoy" (affectionate, like her smile), "laskayushchimi glazami" (caressing eyes). All uses, like those of G. V. Ivanov, are connected with people and their actions. The words are included in the frequency dictionary of fiction with the following indicators: laska (affection) - 18.6 uses per million words of fiction (13.5 per million words of texts of various genres), respectively: laskovo (affectionately) - 48.4 (23.6), laskovyy (affectionate) - 39.8 (24.1) [12]. The number of words in the story is 327 times less than the control sample. Therefore, six uses in the story are a significant excess of the average frequency. Naturally, a person who directly and indirectly quotes a story in his poem, that is, treats it with the utmost attention and involvement, could not consciously or unconsciously notice this excess in frequency. It was the impetus for the characterization of the dance.

There are other intertextual manifestations.

The word ball, which ends the poem, in the story, besides its title, is directly repeated 6 more times: "My main pleasure was parties and balls"; " $<\ldots>$ I was on the last day of Shrovetide at the ball of the provincial leader"; "The ball was wonderful $<\ldots$.. "; " $<$... $>$ as happens at the end of the ball <... "; "My brother didn't like high life at all and didn't go to balls <..."; "I left the ball at five o'clock <...>". Here, too, a clear exaggeration of the frequency. The frequency dictionary indicates 14.7 uses per million words in texts of any genres, but this word is not includes in the frequency dictionary of fiction [12]. In addition to its frequency in the story, the importance of the lexeme is emphasized by its absolutely strong position at the beginning of the text. While Ivanov uses the strong position of the end for the same purpose.

There are two references to evil in the story: " $<\ldots>$ I was not me, but some kind of unearthly creature that did not know evil and was capable only of good"; " $<$... $>$ he, frowning menacingly and viciously, hastily turned away."

Present in the story are also such contexts that combine several components of vocabulary relevant for the poem: "The ball was wonderful: the hall was beautiful, with choirs, musicians - then famous serfs of a landlord-dilettante, a magnificent buffet and a spilled sea of champagne. Although I was keen on champagne, I didn't drink because I was drunk with love, but I danced till I was ready to drop. I danced both quadrilles and waltzes and polkas, of course, as far as possible, with Varenka" [18, p. 9].

All these connections between the two texts appear and are significant only in their integrity. They mutually confirm the functionality of each other and only in integrity they can be considered connections. Being isolated from each other, they can assume completely different interpretations.

The theme of death in the poem is named seven times: potassium cyanide ( 2 times epigraph and text) and mercuric chloride lead to death; vicious, evil cause death; afterlife denotes the kingdom of death; oblivion (in the epigraph) is an attribute of death. Death is mentioned through its general, immediate causes and characteristics.

The statement about the fundamental change in the character of life of the nobility was repeated five times: "became indiscriminate", "drink vodka", "eat poison", that is, destroy themselves; "got used to all this", "actually ceasing to be themselves, retained the mind". All these statements are contextual semantic synonyms, where the dominant of the synonymous 
series is "Well, got used to it". This statement turns out to be the broadest in terms of semantics for everything else: they are accustomed to lack of fastidiousness, vodka, poison, rationalness. The theme of the ball in the poem is named four times: Nui, spin, waltz, ball.

References to G. V. Adamovich were repeated four times: an epigraph; mentioning potassium cyanide; general semantics of death ("oblivion" and "afterlife"); the poems "A shabby jacket with squirrel fur..." and "How picky were you once..." consist of three stanzas.

Despite an abundance of repetitions in such a small text, no hint of semantic redundancy or tautology is created in it. This is due to the fact that repetitions are implemented through synonymous substitutions of various types: the implied and verbally expressed information is repeated. And the latter is organized so that alternating repetitions of various topics lead to the effect of heterogeneity of content.

These repetitions are the connecting links between the five statements that are already interconnected. As a result, in addition to syntagmatic connectedness, the text also acquires a paradigmatic (synonyms - variants of the transmission of meaning) and pragmatic (unity of the produced associations). Together, this creates a high degree of substantial cohesion and compression. An analogue is an object with constant transverse and longitudinal screeds.

The text begins with a presupposition, and ends with an implied consequence. Its beginning and end are outside the book sheet. Their semantics captures and prospectively affirms what is no longer there and what is not here yet. The worlds of the past and the future are deeply anonymous. But this antonymy is the pillar or conceptual basis of the ambivalence of the author's view. G. V. Ivanov is sad with a touch of joy. His lyrical hero marks the position of the wise observer of the wheel of samsara. And in this sense, he is also similar to L. N. Tolstoy. Both, archaizing the ideal and stating its absence in the modern world, find the strength to smile.

Two more communities are organically added to this. It is the general simplicity and transparency of the style, characteristic of the late L. N. Tolstoy and all the works of G. V. Ivanov, which manifests itself in the almost complete absence of visual means and the syntax without complicating components. It is the general almost marginal detachment of the author's position, which manifests itself in the absence of a pronounced author's assessment and ambivalence. Tolstoy and Ivanov state facts that speak by the nature of their selection, and not by the comments accompanying them. Despite the fact that in both texts the authors are formally included in the narrative, meaningfully they are distanced from it.

But with all these similarities, there is a significant difference as well. The prose of Tolstoy is approaching hyperrealism in terms of detail. The poetry of Ivanov is moving in a different direction. His texts strive for the maximum degree of abstractness, within the framework of which, familiar categories disperse and merge with pure creative impulses.

\section{СПИСОК ЛИТЕРАТУРЫ}

1 Авраменко А. П. Георгий Иванов: «диалог» с А. Блоком // Stephanos. 2013. № 1 (1). C. 125-136.

2 Анненков Ю. П. Дневник моих встреч: Цикл трагедий: в 2 т. / предисл. Е. И. Замятина. Л.: Искусство, 1991. Т. 1. 343 с.

3 Бердяев Н. А. Л. Толстой в русской революции // Духовная трагедия Льва Толстого. М.: Подворье Свято-Троицкой Сергиевой Лавры; Отчий дом, 1995. 320 с.

4 Богомолов Н. А. Русская литература первой трети XX века. Портреты. Проблемы. Разыскания. Томск: Водолей, 1999. 639 с. 
5 Василькова Г. С. «Распад атома» Георгия Иванова как «эхо» Пушкинских дней 1937 года в русском зарубежье // Вестник ПсковГУ. 2017. № 5. С. 82-91.

6 Жаравина Л. В. Художественный образ в пространстве виртуала: «Двояковыпуклая линза» Варлама Шаламова и «Талант двойного зренья» Георгия Иванова // Известия ВГСПУ. 2018. № 10 (133). С. 186-192.

7 Закуренко А. Ю. Два образа пустоты. Георгий Иванов, Иосиф Бродский // Страницы: богословие, культура, образование. 2010. Т. 14, № 4. С. 569-577.

8 Иванов Г. В. Собр. соч.: в 3 т. М.: Согласие, 1993. Т. 1: Стихотворения. 656 с.

9 Коростелев О. А., Кузнецова Е. В. Иван Бунин и Георгий Иванов: спор о поэзии длиною в жизнь // Вестник ТГУ. Филология. 2018. № 56. С. 226-247.

10 Лопачева М. К. «Белая лошадь бредет без упряжки...»: И. Бунин и Г. Иванов // Вестник СПбГУКИ. 2014. № 4 (21). С. 146-151.

11 Лопачева M. К. «Бобок будет сериозный...»: Достоевский в художественном мире Георгия Иванова // Русская литература. 2012. № 3. С. 191-204.

12 Ляшевская О. Н., Шаров С. А. Частотный словарь современного русского языка (на мат. Национального корпуса русского языка). М.: Азбуковник, 2009. 1087 с.

13 Национальный корпус русского языка. URL: http://ruscorpora.ru/new/ (дата обращения: 29.10.2019).

14 Папоркова Н. А. Образ души и категория вечности в лирике Лермонтова, Анненского и Георгия Иванова // Альманах современной науки и образования. 2008. № 2 (9). С. 138-140.

15 Семина A. A. Антиномия прекрасного и безобразного в поэтическом тексте: Георгий Иванов и Борис Рыжий // Вестник славянских культур. 2017. Т. 43. С. $178-188$.

16 Семина A. A. «Распад» в творчестве Георгия Иванова и Сергея Чудакова: генетика фрагментарности // Вестник САФУ. 2018. № 1. С. 128-137.

17 Тарасова И. А. «Каждый бы подумал, как подумал Пушкин»: когнитивные механизмы интертекстуальности // Художественный текст как динамическая система. Мат. Междунар. научн. конф., посвящ. 80-летию В. П. Григорьева / отв. ред. Н. А. Фатеева. М.: Азбуковник: ИРЯ им. В. В. Виноградова РАН, 2006. С. $95-103$.

18 Толстой Л. Н. После бала // Толстой Л. Н. Собр. соч.: в 22 т. М.: Худож. лит., 1983. T. 14. C. 7-16.

19 Шраговии Е. Б. Перекличка трех поэтов: Окуджава, Георгий Иванов, Тютчев // Звезда. 2011. № 7. С. 206-212.

\section{REFERENCES}

1 Avramenko A. P. Georgii Ivanov: "dialog" s A. Blokom [George Ivanov: "dialogue" with A. Blok]. Stephanos, 2013, no 1 (1), pp. 125-136. (In Russian)

2 Annenkov Iu. P. Dnevnik moikh vstrech: Tsikl tragedii: $v 2 t$. [Diary of my meetings: The cycle of tragedies: in 2 vols.], preface by E. I. Zamiatin. Leningrad, Iskusstvo Publ., 1991. Vol. 1. 343 p. (In Russian)

3 Berdiaev N. A. L. Tolstoi v russkoi revoliutsii [A. L. Tolstoy in the Russian revolution]. In: Dukhovnaia tragediia L'va Tolstogo [The spiritual tragedy of Leo Tolstoy]. Moscow, Podvor'e Sviato-Troitskoi Sergievoi Lavry, Otchii dom Publ., 1995. 320 p. (In Russian) 
4 Bogomolov N. A. Russkaia literatura pervoi treti XX veka Portrety. Problemy. Razyskaniia [Russian literature of the first third of the $20^{\text {th }}$ century. Portraits. Problems. Searches]. Tomsk, Vodolei Publ., 1999. 639 p. (In Russian)

5 Vasil'kova G. S. "Raspad atoma" Georgiia Ivanova kak «ekho» Pushkinskikh dnei 1937 goda v russkom zarubezh'e [George Ivanov's “The Atom's Decomposition” as a Postscript to the Pushkin Days of 1937 in Russian Émigré]. Vestnik PskovGU, 2017, no 5, pp. 82-91. (In Russian)

6 Zharavina L. V. Khudozhestvennyi obraz v prostranstve virtuala: "Dvoiakovypuklaia linza" Varlama Shalamova i "Talant dvoinogo zren'ia" Georgiia Ivanova [Artistic image in a virtual space: "Biconvex lens" by Varlam Shalamov and "Double-vision Talent" by George Ivanov]. Izvestiia VGSPU, 2018, no 10 (133), pp. 186-192. (In Russian)

7 Zakurenko A. Iu. Dva obraza pustoty. Georgii Ivanov, Iosif Brodskii [Two images of emptiness. George Ivanov, Joseph Brodsky]. Stranitsy: bogoslovie, kul'tura, obrazovanie, 2010, vol. 14, no 4, pp. 569-577. (In Russian)

8 Ivanov G. V. Sobranie sochinenii: v 3 t. [Collected works: in 3 vols.]. Moscow, Soglasie Publ., 1993. Vol. 1: Stikhotvoreniia [Poems]. 656 p. (In Russian)

9 Korostelev O. A., Kuznetsova E. V. Ivan Bunin i Georgii Ivanov: spor o poezii dlinoiu v zhizn' [Ivan Bunin and George Ivanov: a lifelong debate about poetry]. Vestnik TGU. Filologiia, 2018, no 56, pp. 226-247. (In Russian)

10 Lopacheva M. K. "Belaia loshad' bredet bez upriazhki...": I. Bunin i G. Ivanov [“A white horse wanders without a harness...": I. Bunin and G. Ivanov]. Vestnik SPbGUKI, 2014, no 4 (21), pp. 146-151. (In Russian)

11 Lopacheva M. K. "Bobok budet serioznyi...": Dostoevskii v khudozhestvennom mire Georgiia Ivanova ["Little bean will be serious..." Dostoevsky in the artistic world of George Ivanov]. Russkaia literature, 2012, no 3, pp. 191-204. (In Russian)

12 Liashevskaia O. N., Sharov S. A. Chastotnyi slovar' sovremennogo russkogo iazyka (na materialakh Natsional'nogo korpusa russkogo iazyka) [Frequency Dictionary of the Modern Russian Language (based on the materials of the National Corps of the Russian Language)]. Moscow, Azbukovnik Publ., 2009. 1087 p. (In Russian)

13 Natsional'nyi korpus russkogo iazyka [The National Corps of the Russian Language]. Available at: http://ruscorpora.ru/new/ (accessed 29 October 2019). (In Russian)

14 Paporkova N. A. Obraz dushi i kategoriia vechnosti v lirike Lermontova, Annenskogo i Georgiia Ivanova [The image of soul and category of eternity in the lyrics of Lermontov, Annensky and George Ivanov]. Al'manakh sovremennoi nauki i obrazovaniia, 2008, no 2 (9), pp. 138-140. (In Russian)

15 Semina A. A. Antinomiia prekrasnogo i bezobraznogo v poeticheskom tekste: Georgii Ivanov i Boris Ryzhii [The antinomy of the beautiful and the ugly in a poetic text: George Ivanov and Boris Ryzhiy]. Vestnik slavianskikh kul'tur, 2017, vol. 43, pp. 178-188. (In Russian)

16 Semina A. A. "Raspad" v tvorchestve Georgiia Ivanova i Sergeia Chudakova: genetika fragmentarnosti ["Decay" in the works of George Ivanov and Sergei Chudakov: the genetics of fragmentation]. Vestnik SAFU, 2018, no 1, pp. 128-137. (In Russian)

17 Tarasova I.A. "Kazhdyi by podumal, kak podumal Pushkin": kognitivnye mekhanizmy intertekstual'nosti ["Everyone would think the way Pushkin thought": cognitive mechanisms of intertextuality]. In: Khudozhestvennyi tekst kak dinamicheskaia sistema. Materialy Mezhdunarodnoi nauchnoi konferentsii, posviashchennoi 80-letiiu V. P. Grigor'eva [Artistic text as a dynamic system. Proceedings of the International 
scientific conference dedicated to the 80th anniversary of V. P. Grigoriev], executive editor N. A. Fateeva. Moscow, Azbukovnik, RLI RAS Publ., 2006, pp. 95-103. (In Russian)

18 Tolstoi L. N. Posle bala [After the Ball]. In: Tolstoi L. N. Sobranie sochinenii: $v 22 t$. [Collected works: in 22 vols.]. Moscow, Khudozhestvennaia literature Publ., 1983, vol. 14, pp. 7-16. (In Russian)

19 Shragovits E. B. Pereklichka trekh poetov: Okudzhava, Georgii Ivanov, Tiutchev [Cross-talk of three poets: Okudzhava, Georgy Ivanov, Tyutchev]. Zvezda, 2011, no 7, pp. 206-212. (In Russian) 